Crop Breeding and Applied Biotechnology 15: 251-257, 2015

Brazilian Society of Plant Breeding. Printed in Brazil

\title{
ARTICLE
}

http://dx.doi.org/10.1590/1984-70332015v15n4a42

\section{Evaluation of aluminum resistance in hybrids of Brachiaria decumbens Stapf.}

Keise Mara Belmonte de Oliveira ${ }^{1}$, Sanzio Carvalho Lima Barrios ${ }^{2 *}$, Lucimara Chiari² ${ }^{2}$ Valdemir Antônio Laura ${ }^{2}$ and Cacilda Borges do Valle ${ }^{2}$

Received 20 October 2014

Accepted 07 May 2015

\begin{abstract}
The objective of this work was to evaluate hybrids of Brachiaria decumbens for root vigor and aluminum resistance as components of edaphic adaptation. One hundred intraspecific hybrids and their parents were evaluated in a greenhouse solutionculture. Significant differences for both traits indicate that there is genetic variability amongst hybrids. The parents had a similar performance for root growth, but differed significantly for aluminum resistance. Twenty three and seven hybrids were superior to cv. Basilisk for root vigor and aluminum resistance, respectively, but most of them were not coincident for both traits. Aluminum resistance seemed to vary quantitatively, since the majority of the hybrids were placed around the mean and fewer in the extremes. The estimate of heritability based on progeny means for aluminum resistance (0.27) was lower than for root vigor (0.69). The method used was efficient in discriminating hybrids, and identified the best ones for edaphic adaptation.
\end{abstract}

Key words: Signalgrass, abiotic stress, acid soils, heritability, recurrent selection.

\section{INTRODUCTION}

Brazil is the world's largest beef exporter with the world's largest commercial cattle herd maintained almost exclusively in cultivated pastures, observing animal welfare conditions (Figueiredo et al. 2012, Assis et al. 2014). This reduces the cost of production, and confers a competitive advantage to the Brazilian beef production system. The total grassland area in the country is 190 million hectares, and of these, 74 million are native and 116 million are cultivated pastures (Anualpec 2008). Brachiaria spp. represents a large part $(85 \%)$ of the cultivated pastures in the country. Most of the Brazilian pastures are located in the savannas (Cerrado), which are characterized by acid and low fertility soils magnified by a combination of nutrient deficiencies (most significantly $\mathrm{P}$, but also $\mathrm{Ca}, \mathrm{Mg}$, Mo, and sometimes $\mathrm{N}$ and $\mathrm{K}$ ), and mineral toxicities (specially Al) (Rao et al. 1993, Sánchez 1997).

High levels of toxic aluminum in the soil solution impair root growth rate, and also reduce root numbers and length, which interferes in the absorption, transportation and use of nutrients $\left(\mathrm{Ca}^{2+}, \mathrm{Mg}^{2+}, \mathrm{K}^{2+}\right.$ e P) (Foy 1978, Kochian 1995, Ryan et al. 1995). Acid soils often require lime and fertilizer application to overcome nutrient deficiencies and metal toxicity, as well as to increase crop yield. However, the application of lime to the soil surface does not solve the acidity problem in the lower layers, and liming into great depths is not possible due to technical and economic issues (Echart and Cavalli-Molina 2001).

The search for aluminum-resistant forage cultivars is the most economically viable way to increase yield in acid soils. At CIAT (International Center for Tropical Agriculture), a previous study has confirmed that Brachiaria showed genetic diversity for this trait, and $B$. decumbens $\mathrm{cv}$. Basilisk proved to be the most Al-resistant (Wenzl et al. 2001). Wenzl et al. (2006) developed a methodology to evaluate the edaphic adaptation of brachiaria grass genotypes using vegetative propagules (stem cuttings) grown in solution culture. The procedure was designed to quantify two key components: root vigor and $\mathrm{Al}$ resistance. They evaluated interspecific hybrids of $B$. decumbens and B. ruziziensis. This methodology was incorporated into the breeding program of Brachiaria at CIAT.

At Embrapa Beef Cattle, an Al resistance trial of $B$. decumbens and $B$. ruziziensis genotypes also has confirmed

\footnotetext{
${ }^{1}$ Universidade Federal de Mato Grosso do Sul (UFMS), C.P. 549, 79.070-900, Campo Grande, MS, Brazil

${ }^{2}$ Embrapa Beef Cattle, Avenida Rádio Maia, 830, Zona Rural, 79.106-550, Campo Grande, MS, Brazil. *E-mail: sanzio.barrios@embrapa.br
} 
that there is genetic variability within and between species for this trait (Bitencourt et al. 2011). Thus, the objective of this study was twofold: to evaluate intraspecific hybrids of $B$. decumbens for edaphic adaptation, determining root vigor and aluminum resistance; and to study the inheritance of this trait in order to verify if the progeny maintains the level of adaptation already present in the commercial cultivar ( $B$. decumbens cv. Basilisk) used as male genitor.

\section{MATERIAL AND METHODS}

\section{Plant material}

One hundred hybrids of Brachiaria decumbens and their two parents were evaluated in this study. One of the parents was cv. Basilisk, also used as check. These hybrids were obtained by crossing the apomitic $B$. decumbens $\mathrm{cv}$. Basilisk with the sexual artificial tetraploid plant D24/27. The tetraploid sexual plant was obtained by colchicine treatment of a sexual diploid accession (D24), maintained in a Brachiaria spp. germplasm collection at Embrapa Beef Cattle (Simioni and Valle 2009).

These 102 genotypes have originally been planted in an experimental area at Embrapa Beef Cattle (lat 20 27' $\mathrm{S}$; long $54^{\circ} 37^{\prime} \mathrm{W}$; alt $530 \mathrm{~m}$ asl; distroferric soil; Campo Grande, Mato Grosso do Sul, Brazil) since 2010. Soil from the same site was used to grow enough tillers, under greenhouse conditions, to produce sufficient numbers of stem cuttings for this study. Chemical characteristics of this soil were: $\mathrm{pH} 4.9$ at a soil-to-water ratio of $1: 2.5,0.86 \mathrm{mg}$ $\mathrm{dm}^{-3}$ Mehlich I extracted $\mathrm{P}, 0.79 \mathrm{cmol} \mathrm{dm}^{-3} \mathrm{KCl}$ extracted Al, $0.04 \mathrm{cmol} \mathrm{dm}^{-3}$ Mehlich I extracted K, $0.80 \mathrm{cmol} \mathrm{dm}^{-3}$ $\mathrm{KCl}$ extracted $\mathrm{Ca}$, and $0.45 \mathrm{cmol} \mathrm{dm}^{-3} \mathrm{KCl}$ extracted $\mathrm{Mg}$. Before planting, the soil was mixed with sand at a 3:1 ratio, and distributed into 102 containers, each one holding $5 \mathrm{~kg}$.

Approximately 10 tillers from each of the 102 genotypes were potted into the containers (one genotype per container). Forty-five days after potting, vegetative propagules were produced from tillers with three to five leaves and up to three nodes. The tillers were detached below the lowest node above soil level and transplanted into a nutrient solution in greenhouse for rooting, as described by Wenzl et al. (2006).

\section{Rooting of the cuttings}

The bases of the stem cuttings produced from tillers of potted plants were inserted into 1.5 -cm-thick polyurethane foam discs (diameter $=6 \mathrm{~cm}$ ) and put in polyurethane recipients (length $=16 \mathrm{~cm}$ and diameter $=6 \mathrm{~cm}$ ), floating on a large volume of aerated, commercial nutrient solution - Hidrogood fert (C) (adjusting the $\mathrm{pH}$ to 4.20 with $\mathrm{HCl}$ ).
This solution is used in hydroponics to produce vegetables under controlled conditions. The goal at this stage is to produce stem cuttings with homogenous adventitious roots to be subjected to aluminum resistance evaluation. In a previous test comparing the commercial solution with the one proposed by Wenzl et al. (2003), no differences were found in the adventitious roots growth pattern (results not shown); therefore, for practical purposes, the commercial solution was chosen.

\section{Hybrid evaluation}

Nine days after rooting, three pairs of cuttings from each of the 102 genotypes were selected for within-pair homogeneity. One propagule of each of three pairs was transferred to Solution 1 ( $200 \mathrm{mM} \mathrm{CaCl} 2, \mathrm{pH} 4.20)$, and the other, to Solution 2 (200 mM CaCl2, $200 \mathrm{mM} \mathrm{AlCl} 3, \mathrm{pH}$ 4.20), as described by Wenzl et al. (2006). The $\mathrm{pH}$ of both solutions was adjusted to 4.2 by adding calculated quantities of $\mathrm{HCl}$ and measured with a $\mathrm{pH}$ electrode. The two groups of 306 stem cuttings ( 3 per genotype) were grown in plastic trays ( 25 genotypes per tray and each genotype in an individual polyurethane recipient floating in the solution), arranged in a complete block design with 3 replications. The solutions were continuously aerated and renewed every second day to minimize $\mathrm{pH}$ changes. The length of the Longest Root (LR) was measured at the beginning of the experiment and at harvest, after 21 days of growth.

\section{Data analysis}

The LR data were firstly log transformed (Causton and Venus 1981). The Root Relative Growth (RRG) was calculated for each plot as $R R G=\left(L R_{H}-L R_{B}\right) / L R_{B}$, where $L R_{H}$ is the log-transformed length of the longest root at harvest, and $L R_{B}$ is the log-transformed length of the longest root at the beginning of the experiment. Root vigor was estimated based on the RRG in solution $1\left(R R G_{-A l}\right)$. Aluminum resistance was the ratio between $R R G$ in solution $2\left(R R G_{+A l}\right)$ and RRG in solution $1\left(R R G_{-A l}\right)$.

The root vigor and aluminum resistance data were analyzed using a mixed model approach implemented in the PROC MIXED from SAS software (SAS Institute 2004). The experimental design was a complete randomized block with three replications. The genotypes were considered as random effects and block as fixed effects. The experimental precision was assessed by estimating the accuracy, as proposed by Resende and Duarte (2007). In addition, the heritability based on progeny means was estimated as $\hat{\sigma}_{g}^{2} /\left(\hat{\sigma}_{g}^{2}+\frac{\hat{\sigma}_{e}^{2}}{b}\right)$, where $\hat{\sigma}_{g}^{2}$ is the estimate of genotypic variance between treatments, $\hat{\sigma}_{e}^{2}$ is the estimate of error variance, and $b$ the number of blocks in the experiment. 


\section{RESULTS AND DISCUSSION}

The analysis detected highly significant differences ( $p$ $<0.01)$ for root vigor and significant differences $(\mathrm{p}<0.05)$ for aluminum resistance, indicating that there is genetic variation among the hybrids for these traits. This genetic variability was expected to occur due to the heterozygosity of apomictically reproducing $B$. decumbens $\mathrm{cv}$. Basilisk. It is important to state that this was the first time that intraspecific crosses were produced in $B$. decumbens. So far, cultivar Basilisk has been used only as male genitor in interspecific crosses with artificially tetraploidized sexual B. ruziziensis. With the possibility of accomplishing crosses within this species, alleles fixed in the apomictic genotypes could finally be expressed in the progeny. The heritability amongst progeny means were 0.69 and 0.27 for root vigor and $\mathrm{Al}$ resistance, respectively (Table 1). These results suggest greater chance of selecting genotypically superior hybrids for root vigor than for $\mathrm{Al}$ resistance. For this last case, the lower heritability estimate suggests a quantitative inheritance pattern, with a larger number of genes involved in the control of the trait and each one influenced by the environment.

The estimate of accuracy for root vigor was of 0.83 , and for $\mathrm{Al}$ resistance, 0.52 , which is considered of high to moderate experimental precision, respectively (Resende and Duarte 2007). In the case of Al resistance, the number of replications used (three) guaranteed a moderate experimental precision, but not as high as desirable (accuracy above 0.70 ), which could also have contributed for a lower heritability estimate amongst progeny means (Table 1$)$. Wenzl et al. (2006), evaluating 38 interspecific hybrids (B. ruziziensis $\mathrm{x}$ $B$. decumbens), measured the total root length by scanning stained roots, and analyzed the images with the WinRIZHO software (Régent Instruments Inc., Québec, Canada). Hybrids were then evaluated in 10 subgroups of experiments. The pooled total root length data were log transformed and

Table 1. Estimates of genotypic variance $\left(\hat{\sigma}_{\mathrm{G}}^{2}\right)$, heritability based on progeny means $\left(h_{\overline{\mathrm{z}}}^{2}\right)$, accuracy, general mean, amplitude of variation and parent means for root vigor and aluminum resistance of Brachiaria decumbens hybrids

\begin{tabular}{lcc}
\hline Parameters & Root vigor & Al resistance \\
\hline$\hat{\sigma}_{\mathrm{G}}^{2}$ & $0.0136^{* *}$ & $0.0530^{*}$ \\
$h_{\overline{\mathrm{x}}}^{2}$ & 0.6913 & 0.2740 \\
Accuracy & 0.8314 & 0.5235 \\
General Mean & 0.3018 & 0.9157 \\
BLUP minimum & 0.1322 & 0.7473 \\
BLUP maximum & 0.5461 & 1.6965 \\
Basilisk & 0.3695 & 1.0549 \\
$\mathrm{D} 24 / 27$ & 0.3510 & 0.8321 \\
\hline
\end{tabular}

${ }^{\text {" }} p<0.05$ by the Wald $Z$ test; ${ }^{* *} p<0.01$ by the Wald $Z$ test adjusted for harvest mean and dry weight of stem cutting (Beck et al. 2003, Zeegers et al. 2004). In this study, the 102 genotypes ( 100 hybrids +2 parents) were evaluated at the same time in a single trial; therefore, all hybrids were submitted to the same growth condition (not adjusted for harvest mean to remove variation among replicated experiments). Moreover, the data were not adjusted for dry weight of stem cutting, as described by Wenzl et al. (2003), but were corrected for the length of the longest root at the beginning of the experiment, based on the estimated root relative growth.

For root vigor, the BLUP general mean was 0.30 , with hybrids varying from 0.13 to 0.54 . BLUP values for the male and female genitors, Basilisk (0.37) and D24/27 (0.35), respectively, were higher than the mean for the hybrids (0.30); however, the values were very similar to each other (Table 1 and Figure 1). Considering Figure 1, which shows the BLUP values for hybrids and parents in increasing order, it is possible to note that the parents are very close together, and that several transgressive segregating hybrids were identified, both with inferior and superior performance when compared to the parents. These results show that hybrids with excellent root systems in the absence of $\mathrm{Al}$ can be expected when compared to the commercial cultivar, such as hybrids R151 and R137 (right superior side of Figure 1). Wenzl et al. (2006) evaluated 38 interspecific hybrids, together with parental genotypes Basilisk and $B$. ruziziensis clone 44-02, also identified several hybrids with positive transgressive segregation, which suggests presence of heterosis for this trait. High accuracy $(0.83)$ was obtained in the evaluation of hybrid root vigor, denoting good overall precision. This means that the number of replications and the methodology used to estimate relative root growth in solution 1 was adequate to quantify the differences in root vigor among hybrids. According to Wenzl et al. (2006), root vigor, as measured by this method, probably comprises

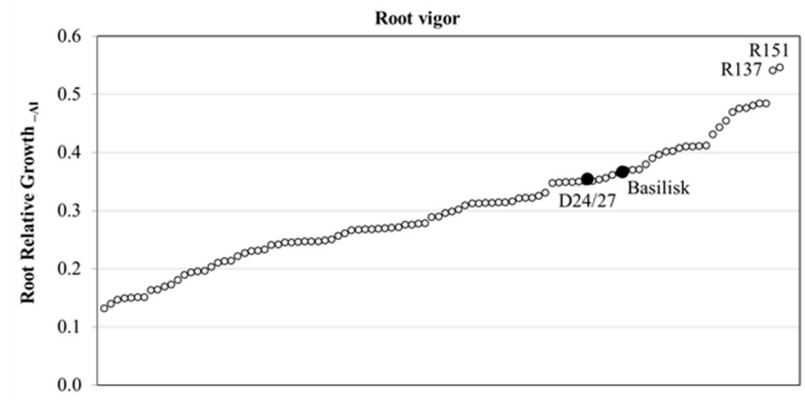

Figure 1. Segregation of root vigor in a group of 100 intraspecific hybrids of $B$. decumbens. Root vigor is the root relative growth in solution $1(200$ $\mathrm{mM} \mathrm{CaCl}, \mathrm{pH}$ 4.20). The two parents are highlighted by black circles. The two hybrids with superior performance are nominated (right upper side). 
different physiological components expressed in plants at a mature, vegetative stage, such as: the frequency of initiation of adventitious roots; the tendency of nutrient-deprived plants to allocate carbon to roots rather than shoots; the efficiency with which nutrient reserves in stem cuttings are remobilized to sustain root growth; the branching of adventitious roots; and the growth of fine roots. Any of these components is likely to have an impact on a plant's adaptation to infertile soils.

Wenzl et al. (2006) explained that root growth in Solution 1 should reflect the plants' ability to produce an extensive root system in order to explore a large volume of soil for nutrient uptake. A comparison of root growth between the two solutions should provide a measure of $\mathrm{Al}$ resistance. However, they reported that aluminum resistance was less straightforward to measure, since the inherent differences in root vigor had to be taken into account to accurately quantify the effect of Al toxicity on root development for the different genotypes. Thus, the authors used a residualvariance approach in order to compute a root vigor-adjusted Al-resistance index. In this case, Al resistance was quantified after regressing the adjusted logarithms of the total root length values from the $\mathrm{Al}$ treatment (Solution 2) on those from the basal treatment (Solution 1), in order to remove the variance component which reflects the inherent differences in root vigor among the hybrids. The residual values after regression were expected to be a more informative measure of true $\mathrm{Al}$ resistance than the original values from the $\mathrm{Al}$ treatment if root vigor and $\mathrm{Al}$ resistance were not correlated (Zeegers et al. 2004). In the present study, the correlation between root vigor, estimated by the Root Relative Growth in solution 1, and aluminum resistance, estimated by the ratio between Root Relative Growth in solution 2 and solution 1 was -0.26 . Despite the weakly negative correlation, this estimate was different from zero $(p<0.01)$, showing that selection to increase root vigor would tend to reduce aluminum resistance. This fact also supports the approach to estimate aluminum resistance based on the ratio between root relative growth in both solutions.

The general BLUP mean for Al resistance was 0.91, with hybrids varying from 0.75 to 1.70 . BLUP value for the male parent Basilisk (1.05) was higher than the hybrids mean (0.91), or the female parent D24/27 mean (0.83), thus indicating that cultivar Basilisk is indeed more resistant than the D24/27 (Table 1). Figure 2 presents the BLUP values of hybrids and parents in increasing order and clearly shows the divergence between the parents in relation to $\mathrm{Al}$ resistance, even if they are similar in root vigor (Figure 1). Some hybrids which presented lower values for root vigor and were very close for that trait also presented divergence for $\mathrm{Al}$ resistance

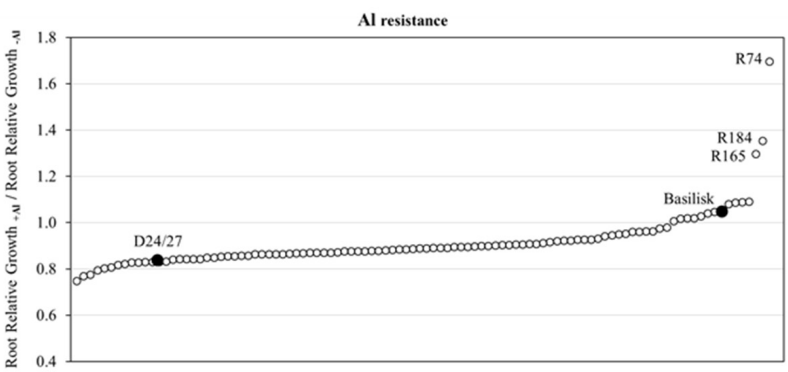

Figure 2. Segregation of $\mathrm{Al}$ resistance in a group of 100 intraspecific hybrids of $B$. decumbens. Al resistance is a ratio between root relative growth $_{+\mathrm{Al}}$ in solution $2\left(200 \mathrm{mM} \mathrm{CaCl}_{2}, 200 \mathrm{mM} \mathrm{AlCl}_{3}, \mathrm{pH} \mathrm{4.20)}\right.$, and root relative growth in solution $1\left(200 \mathrm{mM} \mathrm{CaCl}_{2}, \mathrm{pH}^{4} 4.20\right)$. The two parents are highlighted by black circles. The three hybrids with superior performance are nominated (right upper side).

(R136, R165, R188, among others). These results validate the methodology used in this experiment, which was capable of discriminating genotypes for $\mathrm{Al}$ resistance, even when showing similar root vigor performance. The sexual parent D24/27, despite being a duplicated B. decumbens accession, showed much less resistance to $\mathrm{Al}$ when compared to the male apomictic parent. Bitencourt et al. (2011) evaluated these parents in nutritive solution and did not observe significant differences for main root length between the two solutions (with and without $\mathrm{Al}$ ) for Basilisk, whereas for D24/27, this difference was significant, corroborating the results of this experiment. This difference was also observed in the field, in a distroferric soil, where these parents were evaluated for agronomic traits, and cv. Basilisk had much superior performance when compared to the sexual parent (unpublished data).

Aluminum resistance among hybrids seemed to vary quantitatively, since the majority of the hybrids were placed around the aluminum resistance mean value (0.91), and a fewer number with superior or inferior performance (Figure 2 ). This hypothesis can be supported by the lower estimate of heritability of aluminum resistance $(0.27)$ compared to root vigor (0.69), showing that the aluminum resistance was more influenced by environmental conditions and probably controlled by genes with small effects. Wenzl et al. (2006) evaluating 38 interspecific hybrids (B. ruziziensis $\times$ B . decumbens) for aluminum resistance had already indicated that this trait seemed to vary quantitatively. In Figure 2, it is possible to notice that hybrids R165, R184 and R74 had a remarkable performance for aluminum resistance (right side of Figure 2). Besides these three hybrids, there were some transgressive hybrids with better performance than Basilisk (4 hybrids), but some worse than D24/27 (13 hybrids). The wide difference in aluminum resistance pattern of the parents associated with a small number of 
hybrids with positive transgressive segregation suggests that, in these intraspecific $B$. decumbens hybrids, cultivar Basilisk provided most of the alleles that largely contributed to Al resistance. However, 14 hybrids (R161, R64, R192, R135, R59, R117, R71, R177, R188, R176, R152, R165, $\mathrm{R} 184$ and R74) and also Basilisk had an Al resistance index higher than 1.0, indicating that the root relative growth in solution 2 (with aluminum) was superior when compared with solution 1 (without Aluminum). This is an unexpected and apparently contradictory result, since the presence of aluminum in nutritive solution reduces root growth in many other crops. However, higher estimates of root relative growth in increasing $\mathrm{Al}$ concentration levels have been reported in Brachiaria hybrids (Martins et al. 2010, Miguel et al. 2011). Miguel et al. (2011) evaluating 10 hybrids of Brachiaria ruziziensis in nutritive solution $(0,30$ and $60 \mathrm{mg} / \mathrm{L}$ of $\mathrm{Al})$ found higher differences between final and initial main root length in the highest aluminum concentration, despite the fact that total dry matter of shoots and roots had decreased.

Breeding goals for most forages include combining edaphic adaptation with other important agronomic traits in order to produce superior cultivars. According to Wenzl et al. (2006), edaphic adaptation is difficult to assess since it involves evaluations of pasture persistence across several growing seasons. To help visualize promising genotypes, a two-way graph plotting root vigor and aluminum resistance was simultaneously used in this study (Figure 3). This graph was divided into four quadrants based on the BLUP means of each trait; thus, the identification of hybrids that combine favorable alleles for both traits could be easily seen (Figure 3). Seven hybrids (R74, R184, R165, R152, R177, R176 and $\mathrm{R} 188$ ) had higher Al resistance compared to cv. Basilisk. Of these, two (R152 and R177) also had root vigor higher than the hybrid means and values similar to $\mathrm{cv}$. Basilisk (upper right side of Figure 3). The well-recognized adaptation of cv. Basilisk to infertile and acid soils is probably a consequence of its superior performance for both traits (root vigor and aluminum resistance), as reported by Wenzl et al. (2006) and confirmed in this study.

The presence of a large number of intraspecific hybrids of $B$. decumbens with less aluminum resistance than $\mathrm{cv}$. Basilisk was surprising since most of the accessions in the Brachiaria collection, including the parental material from these hybrids, came from acid soils of the African continent (Valle 1990). These results could be explained by the poor performance of the female genitor (D24/27) for aluminum resistance (Figure 1 and 2), which contributed to the genetic variability observed in the progeny $(p<0.05)$. Thus, $B$. decumbens breeding program needs to enforce aluminum resistance screening in order to develop hybrids with better

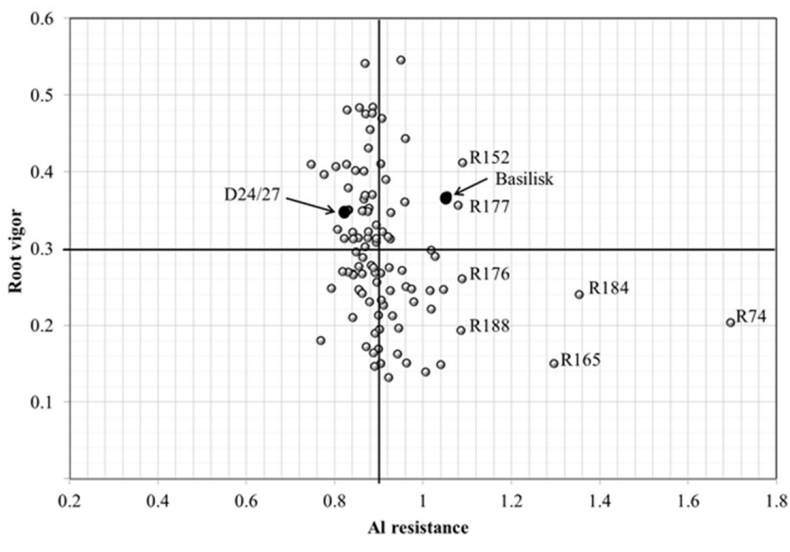

Figure 3. BLUP values of 100 intraspecific hybrids of $B$. decumbens for root vigor and $\mathrm{Al}$ resistance. The vertical and horizontal axis, which divides the graphic into four quadrants, is the BLUP mean value for Al resistance and root vigor, respectively. The two parents are highlighted by black circles. Hybrids with performance superior or similar to $\mathrm{cv}$. Basilisk are nominated.

agronomic performance, nutritive value, spittlebug resistance, and also maintain the aluminum resistance alleles already present in cv. Basilisk (Paulino et al. 1987, Rao et al. 1996, Rao et al. 1998).

Brachiaria decumbens intraspecific hybrids with aluminum resistance higher than or similar to cv. Basilisk were identified in this study using the greenhouse methodology to screen for this trait. Moreover, this approach allowed the selection of hybrids which combine the two component traits related to edaphic adaptation: root vigor and aluminum resistance. This methodology increases the efficiency of the breeding program by the prompt elimination of a large number of non-adapted genotypes, and also allows simultaneous assessment of a single genotype (clone) for other traits, such as insect or disease resistance, nutritional quality, and seed production (Wenzl et al. 2006). At Embrapa Beef Cattle, additional trials that correlate data from the greenhouse methodology and agronomic performance in field conditions will be carried out in order to ensure the proposed methodology for discarding non-adapted hybrids at initial phases of the breeding program. The hybrids evaluated in this work have already been evaluated for agronomic and nutritional traits (Mateus et al. 2013, Mendonça et al. 2013), and are currently being evaluated for spittlebug resistance in greenhouse assays. Four of the seven hybrids which had Al resistance better than cv. Basilisk (Figure 3) had also superior performance for agronomic traits (total dry matter, total leaf dry matter and regrowth), and were placed in the top $25 \%$ rank of a total of 324 hybrids, evaluated in a distroferric soil. Considering the two hybrids (R177 and R152) which combine favorable alleles for aluminum resistance and root 
vigor, hybrid R177 was not only placed in the top $25 \%$ rank for all three agronomic traits evaluated, but also had better regrowth than the check, cv. Basilisk. Other hybrids are also being evaluated for this group of traits (Barrios et al. 2013). A selection index pulling all traits together will be used to select the best sexual hybrids to recombine in an intrapopulacional recurrent selection scheme (sexual population improvement), while superior apomictic hybrids identified are already potential new cultivars, and will be advanced to the next stage of the breeding program.

\section{Avaliação da resistência ao alumínio em híbridos intraespecíficos de Brachiaria decumbens Stapf.}

Resumo - Objetivou-se avaliar híbridos intraespecíficos de Brachiaria decumbens para dois componentes da adaptação edafoclimática: vigor da raiz e resistência a alumínio. Cem híbridos intraespecificos e seus parentais foram avaliados em casa de vegetação. Os híbridos diferiram para ambos os caracteres, indicando a existência de variabilidade genética. Os parentais apresentaram desempenho semelhante para vigor da raiz, mas diferiram para resistência ao alumínio. Vinte e três e sete híbridos foram superiores a cultivar Basilisk para vigor da raiz e resistência a alumínio, respectivamente, porém a maioria não foi coincidente em ambos os caracteres. A herança da resistência ao alumínio aparenta ser quantitativa, visto que a maioria dos híbridos apresentou um desempenho mediano, e poucos nos extremos. A estimativa da herdabilidade com base em médias de progênies para resistência ao alumínio (0,27) foi inferior a do vigor da raiz $(0,69)$. A metodologia utilizada foi eficiente em discriminar e identificar hibridos superiores para adaptação edafoclimática.

Palavras-chave: Capim braquiária, estresse abiótico, solos ácidos, herdabilidade, seleção recorrente.

\section{REFERENCES}

ANUALPEC (2008) Anuário da pecuária brasileira. IFNP, São Paulo, $380 \mathrm{p}$.

Assis GML, Santos CF, Flores PS and Valle CB (2014) Genetic divergence among Brachiaria humidicola (Rendle) Schweick hybrids evaluated in the Western Brazilian Amazon. Crop Breeding and Applied Biotechnology 14: 224-231.

Barrios SCL, Valle CB, Alves GF, Simeão RM and Jank L (2013) Reciprocal recurrent selection in the breeding of Brachiaria decumbens. Tropical Grasslands 1: 52-54.

Beck STR, Brown WM, Williams AH, Pierce J, Rich STS and Langefeld CD (2003) Age-stratified QTL genome scan analyses for anthropometric measures. BMC Genetics 4: S31.

Bitencourt GA, Chiari L, Laura VA, Valle CB, Jank L and Moro JR (2011) Aluminum tolerance on genotypes of signal grass. Revista Brasileira de Zootecnia 40: 245-250.

Causton DR and Venus JC (1981) The biometry of plant growth. Edward Arnold, London, 320p.

Echart CL and Cavalli-Molina S (2001) Fitotoxidade do alumínio: efeitos, mecanismos de tolerância e seu controle genético. Ciência Rural 31: $531-541$.

Figueiredo UJ, Nunes JAR and Valle CB (2012) Estimation of genetic parameters and selection of Brachiaria humidicola progenies using a selection index. Crop Breeding and Applied Biotechnology 12: 237-244.

Foy CD, Chanel RL and Write MC (1978) The physiology of metal toxicity in plants. Annual Review of Plant Physiology and Plant Molecular Biology 29: 511-566.
Kochian LV (1995) Cellular mechanisms of aluminum toxicity and resistance in plants. Annual Review Plant Physiology and Plant Molecular Biology 46: 237-260.

Martins CE, Miguel PSB, Rocha WSD, Sobrinho FS, Gomes FT and Oliveira AV (2010) Seleção de genótipos de Brachiaria ruziziensis quanto à tolerância ao alumínio em solução nutritiva. Revista de Ciências Agrárias 34: 154-162.

Mateus RG, Barrios SCL, Figueiredo UJ and Valle CB (2013) Agronomic evaluation of 324 intraspecific hybrids of Brachiaria decumbens in Brazil. Tropical Grasslands 1: 99-100.

Mendonça AS, Barrios SCL, Figueiredo UJ, Alves GF and Valle CB (2013) Agronomic and nutritional evaluation of intraspecific crosses in Brachiaria decumbens. Tropical Grasslands 1: 103-105.

Miguel PSB, Rocha WSD, Sobrinho FS, Martins CE, Gomes FT, Oliveira AV and Carvalho CA (2011) Seleção de genótipos de Brachiaria ruziziensis quanto ao alumínio em solução nutritiva II. Avaliação da tolerância ao Alumínio. Revista de Ciências Agrárias 34: 163-172.

Paulino VT, Anton DP and Colozza MT (1987) Problemas nutricionais do gênero Brachiaria e algumas relações com o comportamento animal. Zootecnia 25: 215-263.

Rao IM, Kerridge PC and Macedo MCM (1996) Nutritional requirements of Brachiaria and adaptation to acid soils. In: Miles JW, Maass BL, Valle CB (ed.) Brachiaria: Biology, agronomy, and improvement. CIAT, Cali, p. 53-71. (Publication 259).

Rao IM, Miles JW and Granobles JC (1998) Differences in tolerance to infertile acid soil stress among germplasm accessions and genetic recombinants of the tropical forage grass genus, Brachiaria. Field Crops Research 59: 43-52.

Rao IM, Zeigler RS, Vera R and Sarkarung S (1993) Selection and breeding for acid-soil tolerance in crops: Upland rice and tropical forages as 
case studies. Bioscience 43: 454-465.

Resende MDV and Duarte JB (2007) Precisão e controle de qualidade em experimentos de avaliação de cultivares. Pesquisa Agropecuária Tropical 37: 182-194.

Ryan PR, Shaff JE and Kochian LV (1995) Aluminum toxicity in roots: correlation among ionic currents, ion fluxes, and rot elongation in aluminum-sensitive and aluminum-tolerant wheat cultivars. Plant Physiology 99: 1193-1200.

Sánchez PA (1997) Changing tropical soil fertility paradigms: from Brazil to Africa and back. In Moniz AC (ed) Plant-soil interactions at low pH. Brazilian Soil Science Society, Campinas, p. 19-28.

SAS Institute (2004) SAS proprietary software, version 9.12. SAS Institute, Cary, NC, USA.

Simioni C and Valle CB (2009) Chromosome duplication in Brachiaria (A. Rich.) Stapf allows intraspecific crosses. Crop Breeding and Applied Biotechnology 9: 328-334.
Valle CB (1990) Coleção de germoplasma de espécies de Brachiaria no CIAT: estudos básicos visando ao melhoramento genético. Embrapa Gado de Corte, Campo Grande, 33p. (Documentos, 46).

Wenzl P, Arango A, Chaves AL, Buitrago ME, Patiño GM, Miles J and Rao IM (2006) A greenhouse method to screen Brachiariagrass genotypes for Aluminum. Crop Science 46: 968-973.

Wenzl P, Mancilla LI, Mayer JE, Albert R and Rao IM (2003) Simulating infertile acid soils with nutrient solutions: The effects on Brachiaria species. Soil Science Society of America Journal 67: 1457-1469.

Wenzl P, Patiño GM, Chaves AL, Mayer JE and Rao IM (2001) The high level of aluminum resistance in signalgrass is not associated with known mechanisms of external aluminum detoxification in root apices. Plant Physiology 125: 1473-1484.

Zeegers M, Rijsdijk F and Sham P (2004) Adjusting for covariates in variance components QTL linkage analysis. Behavior Genetics 34: $127-133$. 